\section{論 文 Original Paper}

\section{二酸化炭素注入に伴う多孔質砂岩の 透気係数と弾性波速度の测定に関する実験的研究*}

薛自 求 ${ }^{1}$ 大隅多加志 ${ }^{2}$

\title{
Laboratory Measurements on Gas Permeability and P-wave Velocity in Two Porous Sandstones During $\mathrm{CO}_{2}$ Flooding
}

by Ziqiu XUE ${ }^{\mathrm{a} *}$ and Takashi OHSUMI ${ }^{\mathrm{a}}$

a. Research Institute of Innovative Technology for the Earth, Senior Researcher, 9-2, Kizugawadai, Kizu-cho, Soraku-gun, Kyoto, 619-0292, Japan (*Corresponding Author : E-mail xue@rite.or.jp)

\begin{abstract}
Laboratory experiments were conducted to measure gas permeability and P-wave velocity under hydrostatic pressure in Shirahama and Tako sandstones with porosity of $12 \%$ and $24 \%$, respectively. In dry samples, gas permeability and P-wave velocity were significantly changed with increasing hydrostatic pressure in Shirahama sandstone, as a result of the closure of micropores with low aspect ratio, while in Tako sandstone they were less affected. In water-saturated sample, velocity changes caused by $\mathrm{CO}_{2}$ injection, are typically on the order of $-6 \%$. $\mathrm{P}$-wave velocities decreased almost simultaneously along horizontal paths in two orthogonal directions. Results of P-wave velocity tomography suggested that cross-well seismic profiling is useful to monitor migrations of the injected $\mathrm{CO}_{2}$ in geological sequestration sites.
\end{abstract}

KEY WORDS : Carbon Dioxide, Porous Sandstone, P-wave Velocity, Strain, Gas Permeability, Hydrostatic Pressure

\section{1.はじめに}

二酸化炭素 $\left(\mathrm{CO}_{2}\right)$ の地中貯留はノルウェー沖合いにある北海油 田のスライプナー(Sleipner) 鉱区での $\mathrm{CO}_{2}$ 地中圧入事業を機に, 地 球温暖化対策の即効的技術として注目されるようになった。スラ イプナー鉱区では天然ガス精製時に分離した $\mathrm{CO}_{2}$ を海底下約 $1000 \mathrm{~m}$ の帯水層に圧入しており，その事業規模は年間約 100 万 $\mathrm{t}$ となっている ${ }^{1)}$ 。帯水層は主に多孔質砂岩からなっており, $\mathrm{CO}_{2}$ 地中貯留の有望なサイトと期待されている ${ }^{2,3)}$ 。 $\mathrm{CO}_{2}$ を帯水層に圧 入すると，その一部は地層水に溶解寸るが，残りの $\mathrm{CO}_{2}$ は気相を 形成する。地下 $800 \mathrm{~m}$ 以深の帯水層では地温勾配から考えて $31^{\circ} \mathrm{C}$ 以上であり， $\mathrm{CO}_{2}$ は超臨界状態にあるが，その密度は地層水より 小さい。このため, 地層水との密度差によって, $\mathrm{CO}_{2}$ は帯水層上 部一移行寸ると考えられている4)。一方, 溶解した $\mathrm{CO}_{2}$ は地層水 の流れに乗って移動するが, 地層水の移動速度が毎年 $1 \sim 10 \mathrm{~cm}$ と 極めて遅い 5)。したがって, 地中貯留では $\mathrm{CO}_{2}$ を長期にわたって 地下に貯留できるほか，地層を構成する岩石との化学反応により 炭酸塩として固定されることも期待できる ${ }^{6)}$

地中貯留の長期安全性を検討する場合，帯水層に圧入された $\mathrm{CO}_{2}$ の挙動を把握することが重要な研究課題である。帯水層に圧 入された $\mathrm{CO}_{2}$ は岩盤中の間隙水を幾分押し退けながら, 圧入井か ら遠方一広がっていく。その際，岩盤に含まれる地層水の飽和度 は減少し, $\mathrm{CO}_{2}$ 飽和度は増加する。このような $\mathrm{CO}_{2}$ と地層水の置 換プロセスによって, 岩盤を伝播する弾性波速度は減少する。こ

* 2003 年 7 月 16 日受付 12 月 11 日受理

1. 普通会員 (財) 地球環境産業技術研究機構 主任研究員

2. (財) 地球環境産業技術研究機構 主席研究員

[ 著者連絡先] FAX 0774-75-2313 ((財) 地球環境産業技術研究機構・薛)

キーワード : 二酸化炭素，多孔質砂岩，弾性波速度，ひずみ，透気係数，静水圧
のため, 弾性波を用いる物理探査法は $\mathrm{CO}_{2}$ 挙動をモニタリングす る有効なツールとして注目されている7)。一方, $\mathrm{CO}_{2}$ は地層水よ り高い圧力で圧入するため, $\mathrm{CO}_{2}$ 圧入によって地層水の間隙圧が 急激に増加する測定事例が報告されている ${ }^{8)}$ 。 $\mathrm{CO}_{2}$ 圧入に伴って, 地層水の圧力が増加寸る現象は浸透率が $25 \mathrm{md}($ ミリダルシー) 以

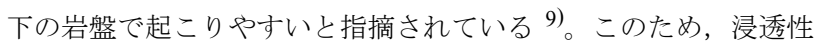
の低い帯水層を対象とする弾性波探查では $\mathrm{CO}_{2}$ 飽和度と水圧上昇 の複合効果を得ていると考えられる。

$\mathrm{CO}_{2}$ 注入による多孔質砂岩の弾性波速度の変化を調べた実験結 果が報告されている ${ }^{10)}$ 。これまでの測定実験では, $\mathrm{CO}_{2}$ 注入に伴 う弾性波速度の変化の計測に留まっており, 注入された $\mathrm{CO}_{2}$ 挙動 の把握には至っていない。本研究では弾性波速度の変化を基に卜 モグラフィ解析によって, 多孔質岩石中を移動する $\mathrm{CO}_{2}$ フロント の挙動をモニタリングすることを試みた。また， $\mathrm{CO}_{2}$ フロントの 挙動が多孔質砂岩の孔隙特性に大きく依存することを考慮して, 孔隙率が異なる 2 種類の砂岩を用いた。本研究では静水圧下で孔 隙特性と密接に関係する透気係数やひずみを把握した上で, $\mathrm{CO}_{2}$ フ ロントのモニタリング実験を行った。弾性波トモグラフィ解析結 果は, 弾性波探査が帯水層に圧入された $\mathrm{CO}_{2}$ のモニタリングッー ルとしての有效性を示している。

\section{2. 実 験 概 要}

\section{$2 \cdot 1$ 岩石試料}

本研究では白浜砂岩 (SS) と多胡砂岩 (TS) を測定試料として用い た。ブロックサンプルから長軸方向が堆積層理面と直交するよう に円柱試料をコアリングした。測定試料の長さと直径はそれぞれ $100 \mathrm{~mm}$ と $50 \mathrm{~mm}$ である。白浜砂岩の孔隙率は約 $12 \%$ であり, Fig.1(a) は水銀ポロシメータによって求めた孔隙半径の分布を示してい 

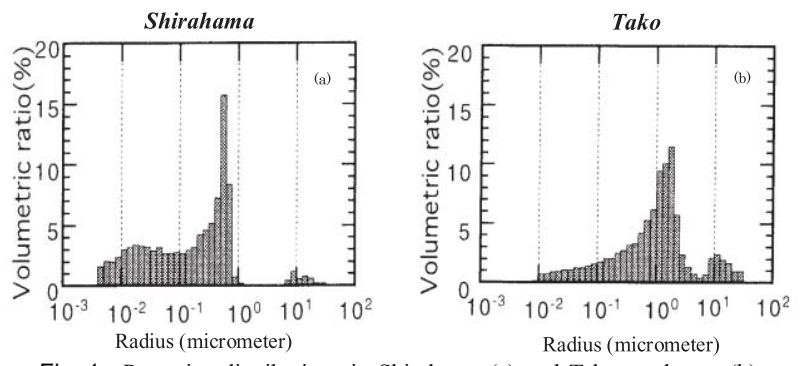

Fig. 1 Pore size distributions in Shirahama (a) and Tako sandstone (b), obtained by the mercury-injection method (after Mino et al.,1989).

る。白浜砂岩の孔隙半径は $0.001 \sim 1 \mu \mathrm{m}$ となっているが，そのう ち $0.8 \mu \mathrm{m}$ の陌が全体の約 $30 \%$ を占めている。一方, 多胡砂岩で は Fig.1(b) に示寸通り, 孔隙半径が $0.01 \sim 10 \mu \mathrm{m}$ となっており, 全 体の約 $30 \%$ が半径 $2 \mu \mathrm{m}$ の孔隙である。多胡砂岩の孔隙率は約 $24 \%$ である。このように，両砂岩の孔隙率と孔隙の大きさには明瞭な 差異が存在する ${ }^{11)}$ 。

Fig.2 は岩石試料に貼り付けた圧電素子とひずみゲージの配置 を示している。円柱試料の側面では弾性波測定用の圧電素子を貼 りつけるために, $90^{\circ}$ 間隔で計 4 箇所に幅約 $8 \mathrm{~mm}$ の面出しを行っ た。各面出し箇所では上から下まで等間隔で $1 \mathrm{MHz}$ の共振周波数 の圧電素子 (P 波) を計 4 個貼り付けた。また，静水圧負荷に伴う 岩石試料の変形を測定するために, 試料側面にはクロスタイプひ ずみゲージ (ゲージ長 : $10 \mathrm{~mm}$ )を計 4 枚貼り付けた。

実験では測定試料を高圧容器にセットする必要があり，圧電素 子とひずみゲージを貼り付けてから試料表面をシリコンゴムで被 覆し，封圧媒体のオイルが試料内部に浸入することを防いだ。

\section{$2 \cdot 2$ 透気試験法}

透気試験法はその測定原理によって圧力制御法と流量制御法に 分類されている ${ }^{12)}$ 。圧力制御法は岩石試料の一端に一定のガス圧 を加え, 反対側の端面から流出する気体の流量を計測し, 透気係 数を求める試験法である。一方, 流量制御法は試料の一端に一定 流量で気体を注入し，それによって生じる試料両端の圧力差を計 測し, 透気係数を求める試験法である。Takeda et al. ${ }^{13)}$ は圧縮空気 を透気媒体として, 同一砂岩試料に圧力制御法と流量制御法をそ れぞれ適用したところ，試験法による透気係数の差異が殆じない ことを確認した。

本研究では圧力制御法を採用しており, 透気試験システムの概念 図をFig.3に示す。ガスボンベより得た $\mathrm{CO}_{2}$ を内容積 $1000 \mathrm{cc}$ の貯 留槽 (耐圧タンク) に充填し, $\mathrm{CO}_{2}$ ガスの温度を室温 $\left(23^{\circ} \mathrm{C}\right)$ に調整 してから測定試料に注入することにした。 $\mathrm{CO}_{2}$ の温度は貯留槽に取 り付けた (株) 東京測器研究所製の温接点加工済久熱電対 (T タイ プ, 温度レンジ: $-270^{\circ} \mathrm{C} \sim+400^{\circ} \mathrm{C}$; 読取り精度 : $\left.0.1{ }^{\circ} \mathrm{C}\right)$ で測定し た。また, $\mathrm{CO}_{2}$ の注入圧は (株)アサヒエンタプライズ社製の小型 高性能デジタルレギュレータ $\mathrm{S} 640$ ( 圧カレンジ : 0 〜 $0.25 \mathrm{MPa} ;$ 精 度 : $\pm 0.5 \%)$ を用いて制御した。測定試料を透過した $\mathrm{CO}_{2}$ の流量は, 予めキャリブレーションされたテフロン製計測チューブに封入し たマノメータオイルの移動距離を基に算出された。また, $\mathrm{CO}_{2}$ 流量 の測定に影響する室内温度変動を抑えるために, エアコンを連続運 転させ，室温を $23^{\circ} \mathrm{C}$ となるように工夫した。透気係数は定常状態 に達してからの流量を基に, 次式より算出される。

$$
k=\frac{2 Q_{g} \eta P_{a}}{A} \cdot \frac{l}{P_{0}^{2}-P_{l}^{2}}
$$

ここで, $k$ は透気係数, $\eta$ は $\mathrm{CO}_{2}$ の粘性係数 $(=14.91 \mu \mathrm{Pa} ・ \mathrm{~s}), \mathrm{Qg}$ は大気圧下における $\mathrm{CO}_{2}$ の流量 $\left(\mathrm{m}^{3} / \mathrm{s}\right), \mathrm{Pa}$ は大気圧 $(\mathrm{Pa}), \mathrm{A}$ は測 定試料の断面積 $\left(\mathrm{m}^{2}\right), l$ は測定試料の長さ $(\mathrm{m}), P_{o}$ と $P_{l}$ はそれぞ れ $\mathrm{CO}_{2}$ 流入側と流出側における絶対圧力 $(\mathrm{Pa})$ である。

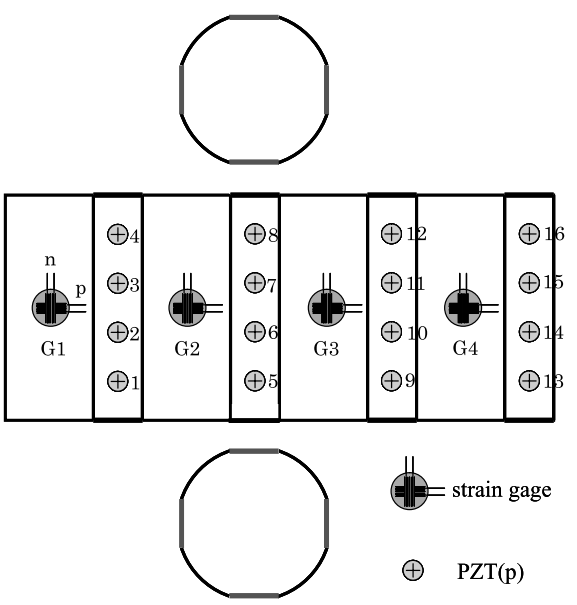

Fig. 2 An unfolding diagram showing locations of piezo-electric transducers and strain gages cemented on the sandstone sample. Sixteen piezo-electric transducers numbered from 1 to 16 , were arranged in $4 \times 4$ to monitor movements of the $\mathrm{CO}_{2}$ front in two orthogonal directions. Letters of $\mathrm{n}$ and $\mathrm{p}$ followed gage numbers indicate strains measured normal and parallel to bedding plane of rock sample, respectively.

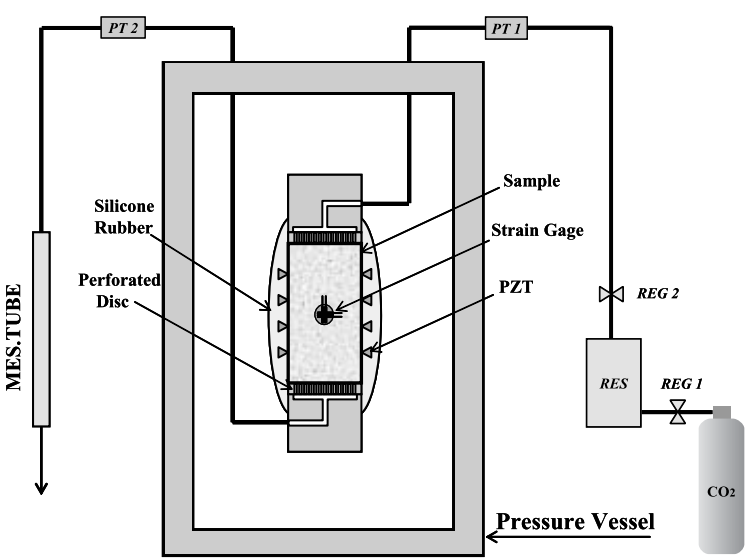

Fig. 3 A schematic diagram of the experimental apparatus. RES $=$ Reservoir tank, REG $1=$ Regulator 1 (Max:0.6MPa), REG 2 = Regulator 2 (Max : 0.2MPa), PT1 and $2=$ Pressure Transducer 1 and 2, MES. TUBE $=$ Measuring Tube for displaced water.

$2 \cdot 3$ 弾性波測定法と $\mathrm{CO}_{2}$ フロントのモニタリング

本研究ではパルス透過法を用いて $\mathrm{P}$ 波速度を測定した。乾燥試 料の透気係数を測定した際, 静水圧の負荷に伴う $\mathrm{P}$ 波速度とひず みの変化も測定した。これらの測定結果は両砂岩の孔隙特性の違 いを検討するために用いた。一方，含水状態の測定試料について は, $\mathrm{CO}_{2}$ ガスを注入しながら, 一定の時間間隔で $\mathrm{P}$ 波速度を測定 し, 孔隙構造中を移動する $\mathrm{CO}_{2}$ の挙動をモニタリングした。P 波 測定では弾性波卜モグラフィ解析が可能となるように, スイッチ アレーシステムが導入された。このシステムではパルスジェネ レータから得たパルス信号を 1 個の圧電素子に与えると, それ以 外の 15 個の圧電素子は順次に受信に切りかえられながら, P 波速 度を測定することができる。ただし, 発信子と同じ列にある圧電 素子に対しては測定経路としない。また, 同じ経路上の発信子と 受信子の切り替えは 1 回しか測定しない。このため, 1 回の計測 では計 96 個の経路 (ray path) の波形データを得ることができる。 受信波形はデジタルオシロスコープで確認しながら, GPIB 経由で コンピュータに記録された。その際, 波形のノイズを減らすため に, 8 回のスタッキング (波形の重叔合せ ) を行った。

$\mathrm{P}$ 波速度を用いてトモグラフィ解析を行うとき, 岩石試料の長 軸を均等に 6 分割した。また, 長軸と直交する平面 (両端面) で は 1 辺の長さが試料直径の $1 / 3$ となる平行四辺形を中心にして, 


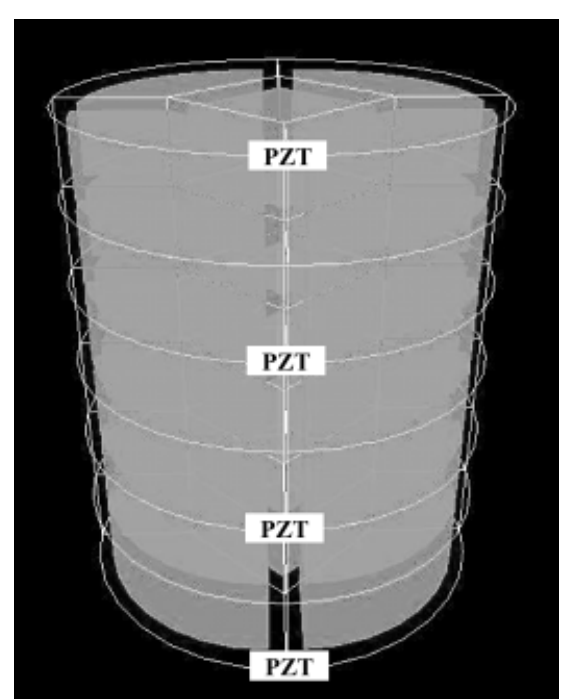

Fig. 4 A 3D view showing 30 blocks for reconstruction of P-wave velocity profiles.
Fig.4のとおり 5 分割した。このように試料全体は計 30 個のブロッ クに分割されたが, 圧電素子の数が少ないため, 弾性波卜モグラ フィ解析では汎用ソフト Mathematica の Interpolation 関数を用い て, 3 次近似でデータ補完を行った。

\section{3. 実 験 結 果}

\section{$3 \cdot 1$ 透気試験の結果}

透気試験では白浜砂岩と多胡砂岩の一軸圧縮強度を考慮して, 静水圧をそれぞれ $25 \mathrm{MPa}$ と $15 \mathrm{MPa}$ まで段階的に負荷しながら透 気係数の変化を測定した。試料の上端より $0.2 \mathrm{MPa}$ の圧力で $\mathrm{CO}_{2}$ ガスを注入し，大気圧下に開放された試料下端から出たガス流量 を基に透気係数を求めた。透気試験で得られた両砂岩のひずみ, $\mathrm{P}$ 波速度及び透気係数の測定結果をそれぞれ Table 1, Table 2 に示 し, 以下ではこれらの結果について述べる。なお, 本研究では圧 縮ひずみを正としている。

（1）静水圧の負荷に伴うひずみの変化

白浜砂岩 $(\mathrm{SS})$ と多胡砂岩 (TS) の測定試料より得たひずみの測定 結果をFig.5 に示す。この図では G1～G4 がひずみゲージの番号

Table 1 Results of gas permeability, velocity and strain obtained from the dry sample of Shirahama sandstone under hydrostatic pressure.

\begin{tabular}{cccccc}
\hline $\begin{array}{c}\text { Pressure } \\
(\mathrm{MPa})\end{array}$ & $\begin{array}{c}\text { Permeability } \\
\left(10^{-4} \text { darcy }\right)\end{array}$ & $\begin{array}{c}\text { Average Velocity } \\
(\mathrm{km} / \mathrm{s})\end{array}$ & $\begin{array}{c}\text { Average Strain_n } \\
(\mu \varepsilon)\end{array}$ & $\begin{array}{c}\text { Average Strain_p } \\
(\mu \varepsilon)\end{array}$ & $\begin{array}{c}\text { Volumetric Strain } \\
(\mu \varepsilon)\end{array}$ \\
\hline \hline 0 & $\cdots \cdots$ & 2.70 & $\cdots \cdots-\cdots$ & $\ldots$ \\
2 & 3.75 & 2.85 & 385 & 338 & 1061 \\
5 & 3.06 & 2.99 & 852 & 713 & 2277 \\
10 & 2.68 & 3.23 & 1538 & 1267 & 4071 \\
15 & 2.51 & 3.41 & 2025 & 1645 & 5314 \\
25 & 2.18 & 3.62 & 2667 & 2173 & 7014 \\
\hline
\end{tabular}

Table 2 Results of gas permeability, velocity and strain obtained from the dry sample of Tako sandstone under hydrostatic pressure.

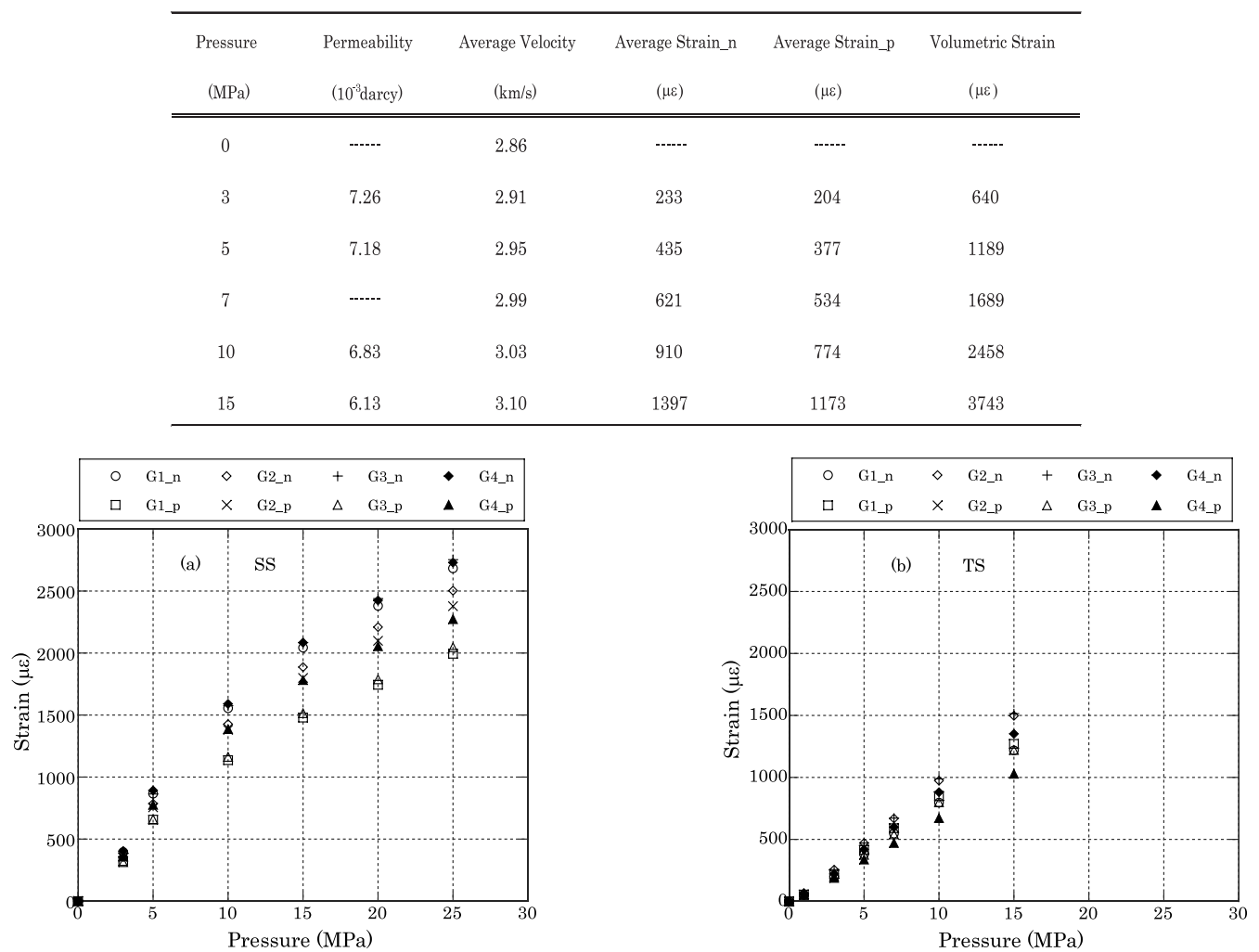

Fig. 5 Strains obtained on Shirahama (a) and Tako sandstone (b) vs pressure. $\mathrm{n}$ and $\mathrm{p}$ indicate strains measured normal and parallel to the bedding plane, respectively. 
である。また，ゲージ番号に続く $\mathrm{n}$ と $\mathrm{p}$ はそれぞれひずみゲージ が堆積層理面に直交と平行することを表している。静水圧の負荷 に伴って, 両砂岩のひずみはともに増加するが, ひずみの増加傾 向が異なっている。試料 SS では $10 \mathrm{MPa}$ まではひずみの増加が著 しいが，圧力が大きくなるにつれて，ひずみの増分が徐々に小さ くなっている (Fig.5a)。一方, 多胡砂岩の場合, Fig.5bのように圧 力の負荷に伴うひずみ増分が小さく, 全体のひずみ量が少ない。 静水圧 $15 \mathrm{MPa}$ 下では白浜砂岩に比べて約 $500 \mu$ ひずみが少ない。

両試料の静水圧〜ひずみ曲線の形状にも違いが認められ，白浜 砂岩では上へ凸となっている。これに対し, 多胡砂岩では低圧領 域ではやや下へ凸となっているが, 高圧領域ではほぼ直線である。 また，堆積層理面と直交する方向 (n) と平行する方向 (p) のひずみ を比較すると, 両試料とも $\mathrm{n}$ 方向のひずみがやや大きく, その差 は静水圧の増加に伴って徐々に大きくなっている。静水圧 $15 \mathrm{MPa}$ における $\mathrm{n}$ 方向と $\mathrm{p}$ 方向のひずみの差を比べると, 白浜砂岩と多 胡砂岩ではそれぞれ最大で約 $500 \mu(\mathrm{G} 1)$ と $400 \mu(\mathrm{G} 4)$ に達している。

（2）静水圧の負荷に伴う $\mathrm{P}$ 波速度の変化

ひずみと同時に測定された試料 SS と TS の P 波速度の結果を Fig.6 に示す。Fig.6a は試料 SS の測定結果であり,この試料では 測定経路による $\mathrm{P}$ 波速度のばらつきが約 $2 \%$ と小さい。 $\mathrm{P}$ 波速度 は静水圧の負荷に伴って大きく増加しており, その増加傾向はひ ずみとよく似ている (Fig.5a 参照)。一方, 試料 TS では P 波速度 のばらつきが約 $8 \%$ に達しており, $\mathrm{P}$ 波速度の急激な増加はみら れなかった (Fig.6b)。静水圧を $15 \mathrm{MPa}$ まで負荷したとき, Table 1 の通り, 試料 SS の $\mathrm{P}$ 波速度は $2.70 \mathrm{~km} / \mathrm{s}$ から $3.41 \mathrm{~km} / \mathrm{s}$ まで増加し た。これに対し, 試料 TS の P 波速度は $2.86 \mathrm{~km} / \mathrm{s}$ から $3.10 \mathrm{~km} / \mathrm{s}$ ま で増加した (Table 2 参照)。P 波速度の増加率に注目すると, 試料 SS が約 26\% の増加を示しており, 試料 TS の $8 \%$ を大きく上回っ
ている。なお, Table 1,2 に示寸 P 波速度の平均值はそれぞれ Fig.6a と Fig.6b のデータに基づいて算出された。

（3）静水圧の負荷に伴う透気係数の変化

Fig.7 は静水圧の負荷に伴う試料 SS と TS の透気係数と体積ひず みの変化を示している。ここでは周方向 $(\mathrm{p})$ のひずみを 2 倍にして から, 長軸方向 (n) のひずみとの和を体積ひずみとして定義してい る。静水圧の増加に伴って, 両試料の透気係数はともに減少する が, 減少率に大きな差異が認められた。試料 SS では静水圧を $2 \mathrm{MPa}$ から $15 \mathrm{MPa}$ まで負荷したとき, 透気係数が $3.75 \times 10^{-4}$ から $2.51 \times$ $10^{-4}$ darcy に減少し, その減少率は約 $32 \%$ であった。一方, 試料 TS では静水圧を $3 \mathrm{MPa}$ から $15 \mathrm{MPa}$ まで負荷したとき, 透気係数は 7.13 $\times 10^{-3}$ から $5.97 \times 10^{-3}$ darcy減少したが, その減少率は約 $16 \%$ に留まっ た。Fig.7 において, 試料 SS では体積ひずみが急激に増加する間で は透気係数が大きく減少した。このような体積ひずみと透気係数の 急激な変化について，試料 TS では認められなかった。

静水圧の増加に伴う体積ひずみと P 波速度の変化を Fig.8 に示 す。この図に示寸 $\mathrm{P}$ 波速度は全チャンネルの $\mathrm{P}$ 波速度を算術平均 したものである。試料 SS では $\mathrm{P}$ 波速度の増加傾向が体積ひずみ とよく似ているが，試料 TS では体積ひずみが大きく増加しても， $\mathrm{P}$ は速度の増分は小さかった。

\section{$3 \cdot 2 \mathrm{CO}_{2}$ 注入による $\mathrm{P}$ 波速度の変化}

(1) 白浜砂岩について

透気試験終了後の試料 SS については, まず静水圧を $7 \mathrm{MPa}$ まで 除荷してから，試料下端より純水を注入した。純水の注入圧は $3 \mathrm{MPa}$ としたが, 注水開始後約 12 時間を経過しても試料全体に水 が浸透しなかった。Fig.9aに示寸通り，水が浸潤した領域 (ch.1-9, 2-10，5-13，6-14) と浸潤していない領域 (ch.3-11，4-12，7-15, 816)のP 波速度には $10 \%$ 以上の差が認められた。この状態で試料
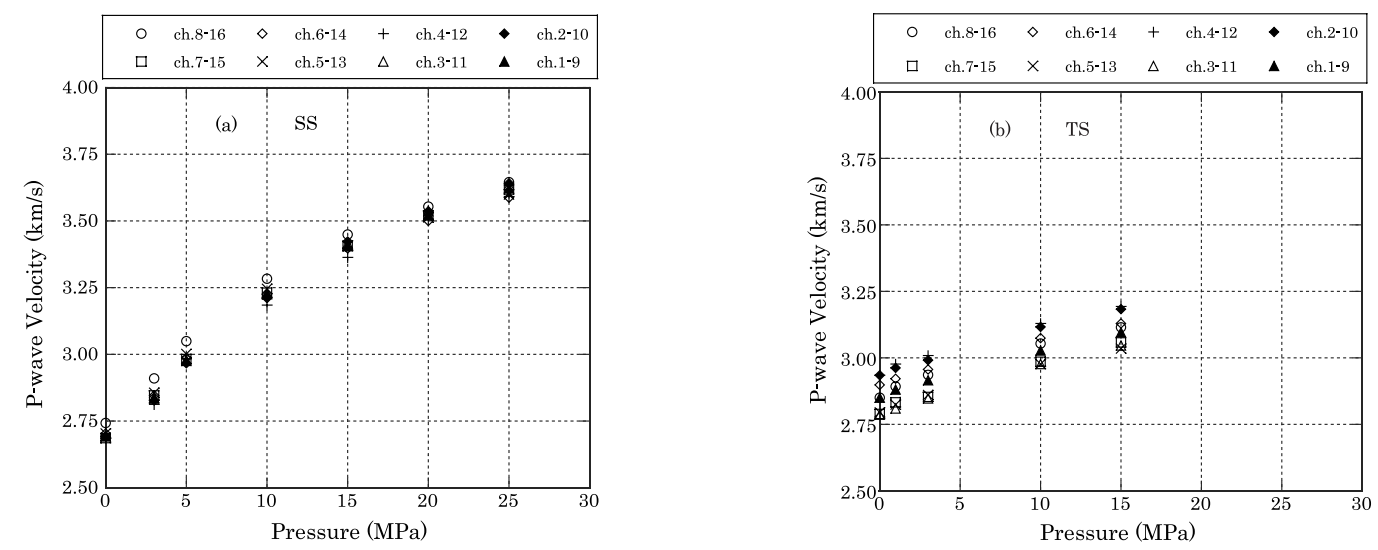

Fig. 6 P-wave velocities measured along eight paths parallel to the end surface of the samples in Shirahama (a) and Tako sandstone (b) vs pressure.
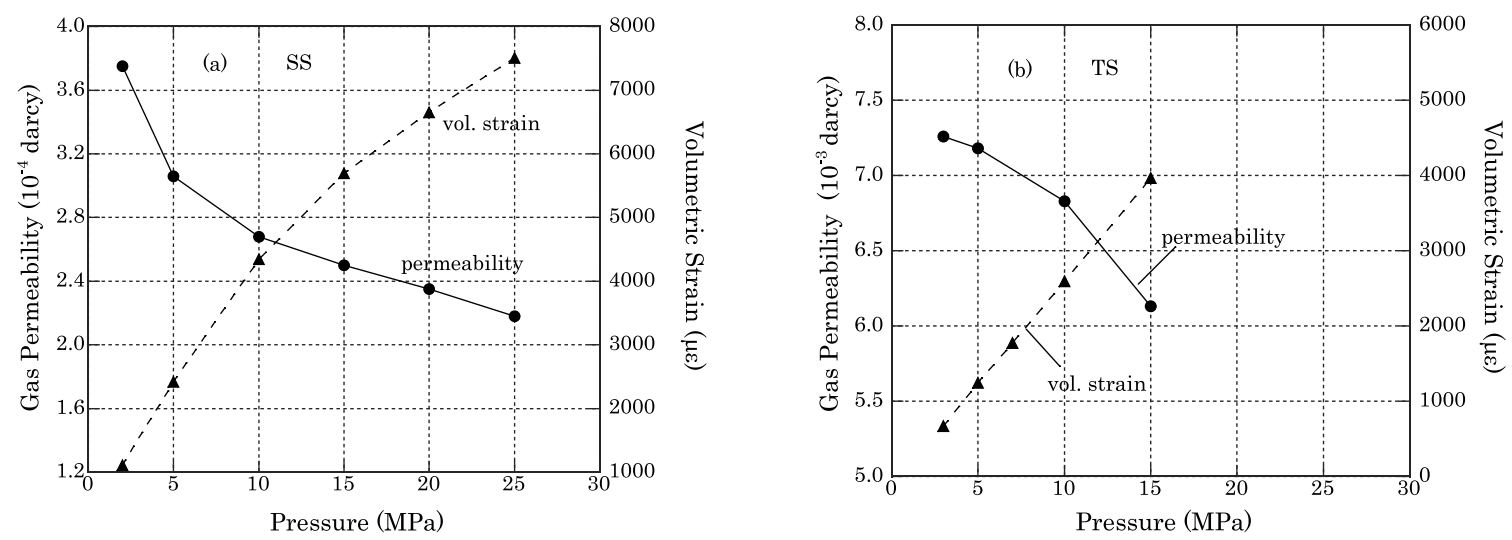

Fig. 7 Gas permeability and volumetric strain as a function of pressure, obtained from Shirahama (a) and Tako sandstone (b). 

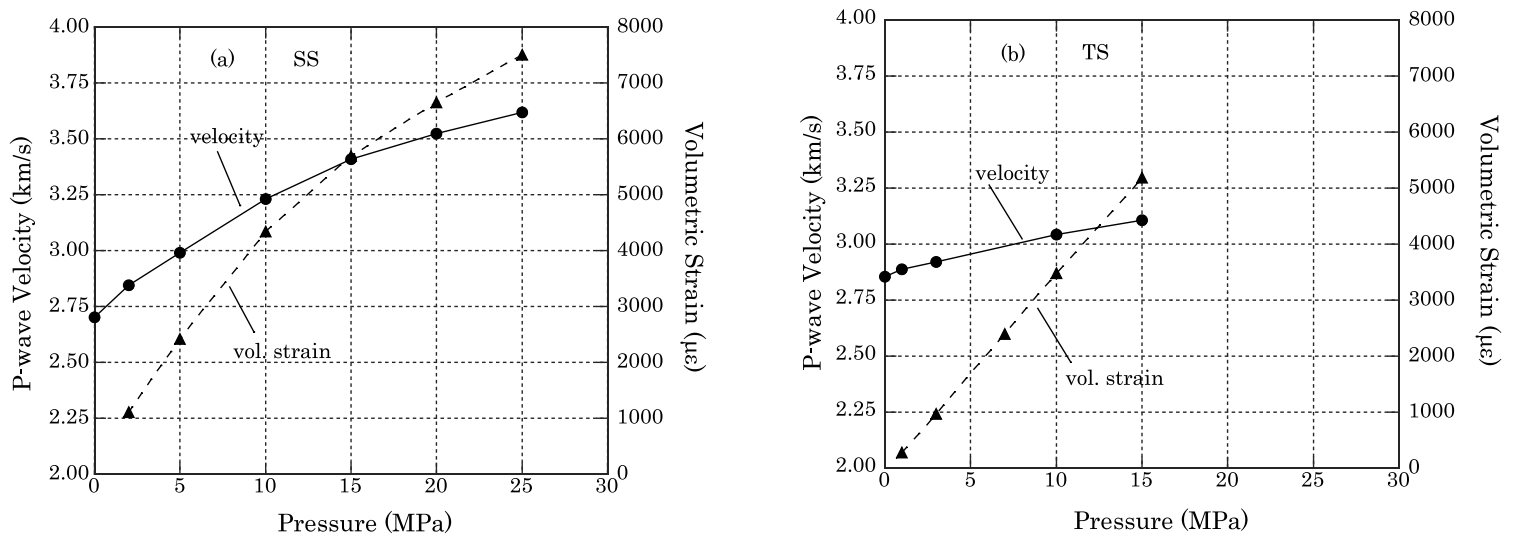

Fig. 8 Average velocity of P-wave and volumetric strain as a function of pressure, obtained from Shirahama (a) and Tako sandstone (b).
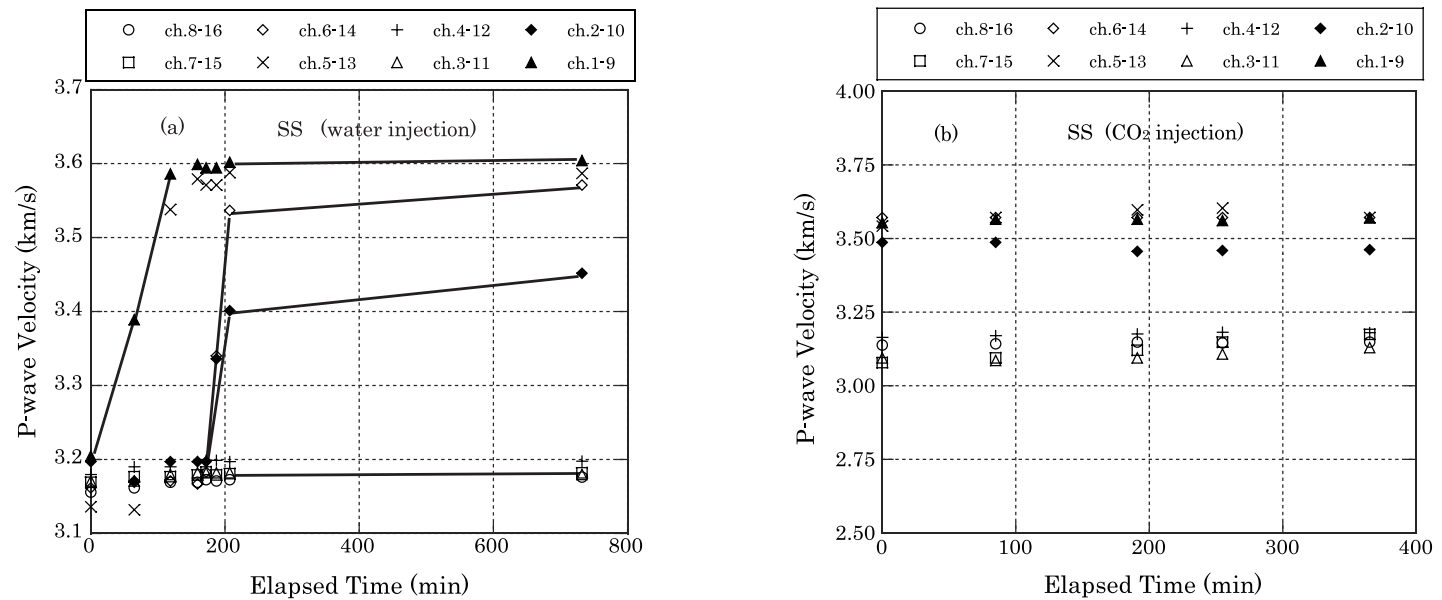

Fig. 9 Changes of P-wave velocity obtained on Shirahama sandstone when injecting water into dry sample (a) and gaseous $\mathrm{CO}_{2}$ gas into the water-flooded sample (b).

下端より $0.2 \mathrm{MPa}$ の圧力で $\mathrm{CO}_{2}$ ガスを注入し, P 波速度の経時変 化を Fig.9b に示した。しかし， $\mathrm{CO}_{2}$ ガスを注入してから約 6 時間 を経過しても浸潤領域の $\mathrm{P}$ 波速度の変化がほとんどみられなかっ た。また, $\mathrm{CO}_{2}$ 注入圧を制御するデジタルレギュレータの使用圧の 制限により，試料 $\mathrm{SS} へ の \mathrm{CO}_{2}$ ガス注入はやむを得ず中断した。

(2) 多胡砂岩について

試料 TS については，静水圧を $5 \mathrm{MPa}$ に除荷してから純水を注入 した。この試料の浸透率が比較的大きいため, 水を浸透させるのに あまり時間がかからなかった。試料 TS については，静水圧 5,10 及び $15 \mathrm{MPa}$ の 3 ケースにおいて，それぞれ含水状態の試料下端よ

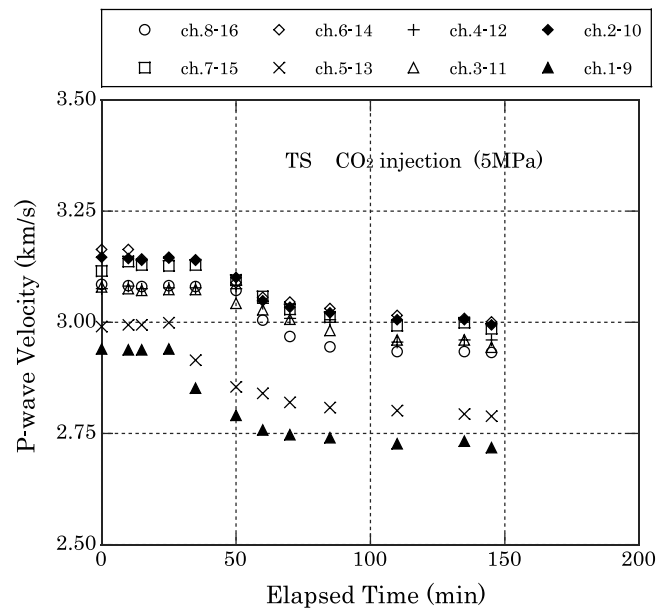

Fig. 10 Changes of $\mathrm{P}$-wave velocity vs elapsed time when injecting gaseous $\mathrm{CO}_{2}$ into the water-saturated Tako sandstone. The sample was subjected to a constant pressure of $5 \mathrm{MPa}$.
り $\mathrm{CO}_{2}$ ガスを注入しながら $\mathrm{P}$ 波速度の変化を測定した。なお，静 水圧 10 と $15 \mathrm{MPa}$ のケースではともに前の測定終了後に純水を透過 させた。測定試料に残留する $\mathrm{CO}_{2}$ などを取り除くために，十分に 長い時間をかけて純水を注入してから次の $\mathrm{CO}_{2}$ 注入実験に備えた。

含水状態の多胡砂岩に $\mathrm{CO}_{2}$ ガスを注入すると, 間隙水の一部が 置換され，試料上端より排出される。実験では試料上端の間隙水圧 ラインを大気圧に開放し, 間隙水圧の上昇による $\mathrm{P}$ 波速度への影響 を抑えた。また, $\mathrm{CO}_{2}$ 注入によって置換される少量の間隙水を早期 に検出できるように，排水側の圧力ラインを水で満たしておいた。

Fig.10, Fig.11，Fig.12 は含水状態の試料 TS にそれぞれ 5, 10

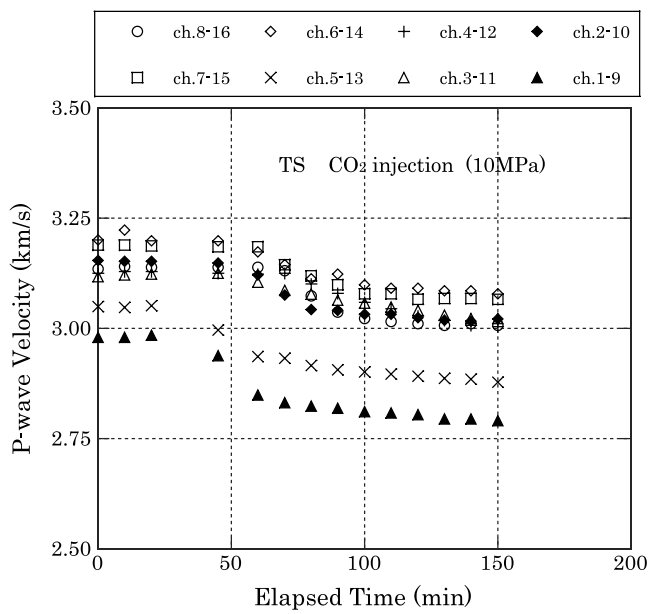

Fig. 11 Changes of P-wave velocity vs elapsed time when injecting gaseous $\mathrm{CO}_{2}$ into the water-saturated Tako sandstone. The sample was subjected to a constant pressure of $10 \mathrm{MPa}$. 


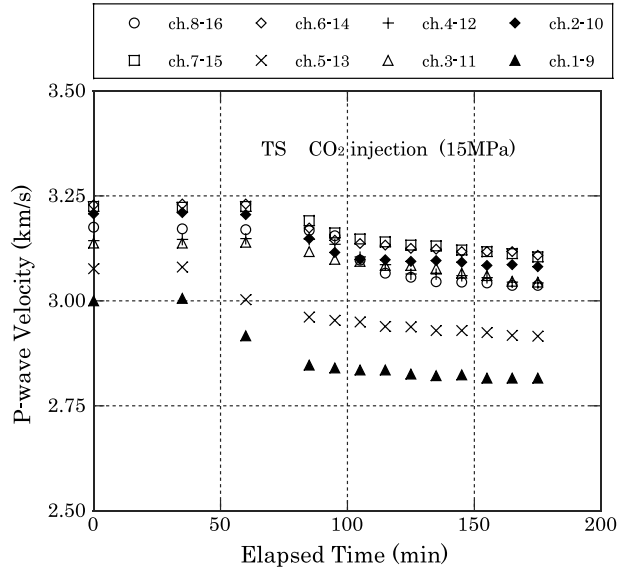

Fig. 12 Changes of P-wave velocity vs elapsed time when injecting gaseous $\mathrm{CO}_{2}$ into the water-saturated Tako sandstone. The sample was subjected to a constant pressure of $15 \mathrm{MPa}$.

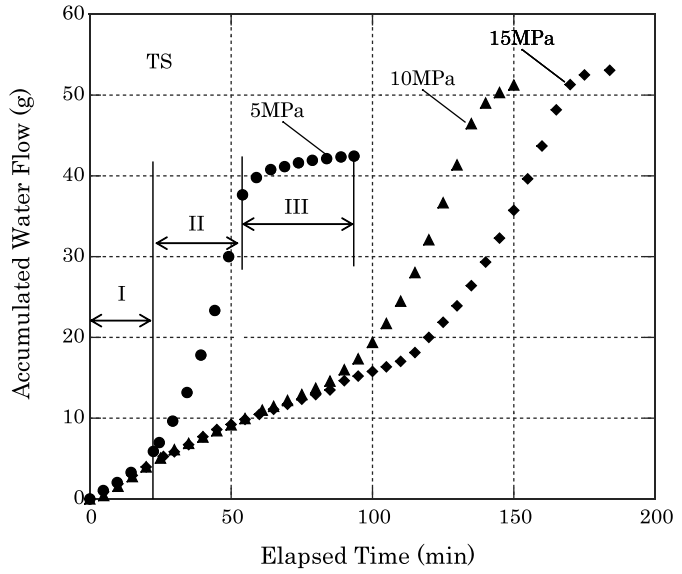

Fig. 13 The accumulated water flow obtained from the water-saturated Tako sandstone during $\mathrm{CO}_{2}$ injection. Three measurements were repeated on the same sample under pressures of 5, 10 and $15 \mathrm{MPa}$.

Table 3 Results of velocity changes when injecting gaseous $\mathrm{CO}_{2}$ into water-saturated Tako sandstone under pressures of 5, 10 and $15 \mathrm{MPa}$, respectively.

\begin{tabular}{c|ccc|ccc|ccc}
\hline & \multicolumn{3}{|c|}{$5 \mathrm{MPa}$} & \multicolumn{3}{c|}{$10 \mathrm{MPa}$} & \multicolumn{3}{c}{$15 \mathrm{MPa}$} \\
\cline { 2 - 9 } Ray Path & $\mathrm{V}_{0}$ & $\mathrm{~V}_{145}$ & $\Delta \mathrm{V} / \mathrm{V}_{0}(\%)$ & $\mathrm{V}_{0}$ & $\mathrm{~V}_{145}$ & $\Delta \mathrm{V} / \mathrm{V}_{0}(\%)$ & $\mathrm{V}_{0}$ & $\mathrm{~V}_{145}$ & $\Delta \mathrm{V} / \mathrm{V}_{0}(\%)$ \\
\hline \hline ch.8-16 & 3.09 & 2.93 & -4.96 & 3.14 & 3.01 & -3.96 & 3.18 & 3.05 & -4.12 \\
ch.7-15 & 3.12 & 2.99 & -4.14 & 3.19 & 3.07 & -3.86 & 3.23 & 3.12 & -3.22 \\
ch.6-14 & 3.16 & 3.00 & -5.15 & 3.20 & 3.08 & -3.81 & 3.23 & 3.12 & -3.47 \\
ch.5-13 & 2.99 & 2.79 & -6.72 & 3.05 & 2.88 & -5.64 & 3.08 & 2.93 & -4.81 \\
ch.4-12 & 3.08 & 2.96 & -3.77 & 3.13 & 3.00 & -3.87 & 3.14 & 3.06 & -2.67 \\
ch.3-11 & 3.08 & 2.94 & -4.42 & 3.12 & 3.00 & -3.69 & 3.14 & 3.07 & -2.29 \\
ch.2-10 & 3.15 & 2.99 & -4.83 & 3.15 & 3.02 & -4.22 & 3.21 & 3.09 & -3.62 \\
ch.1-9 & 2.94 & 2.72 & -7.55 & 2.98 & 2.79 & -6.34 & 3.00 & 2.82 & -6.00 \\
\hline \hline \multirow{2}{*}{ Average } & 3.07 & 2.92 & -5.19 & 3.12 & 2.98 & -4.42 & 3.15 & 3.03 & -3.78 \\
\hline
\end{tabular}

及び $15 \mathrm{MPa}$ の静水圧を負荷したまま, $\mathrm{CO}_{2}$ ガスを $0.2 \mathrm{MPa}$ で注入 したときの P 波速度の経時変化である。Fig. 10 は静水圧 $5 \mathrm{MPa}$ の 場合の測定結果である。 $\mathrm{CO}_{2}$ 注入開始約 30 分後, まず試料下端に 近いch.1-9のP 波速度が $2.94 \mathrm{~km} / \mathrm{s}$ から $2.85 \mathrm{~km} / \mathrm{s}$ に減少した。この チャンネルと同じ水平面にあり,互いに直交する ch.5-13 の P 波速 度は $2.99 \mathrm{~km} / \mathrm{s}$ から $2.91 \mathrm{~km} / \mathrm{s}$ に減少した。それからさらに 30 分ほ ど経過すると, ch.1-9 と 5-13 の P 波速度はほぼ一定值に収束した。 一方, その他のチャンネルでは $\mathrm{P}$ 波速度が遅れて減少し始めるが, 約 110 分経過後ともにほぼ平衡に達した。

Fig.11 と Fig.12 はそれぞれ静水圧 10 と $15 \mathrm{MPa}$ の場合の測定結 果である。これらの測定ケースでは，静水圧 $5 \mathrm{MPa}$ でみられた $\mathrm{P}$ 波速度の減少傾向とよく似ている。Table 3 は各静水圧下おける $\mathrm{CO}_{2}$ 注入前と注入開始 145 分後の $\mathrm{P}$ 波速度の変化を示している。3 つの測定ケースのうち, 静水圧 $5 \mathrm{MPa}$ の方が最も $\mathrm{P}$ 波速度の減少 率が大きく, 約 $4.1 \sim 7.6 \%$ となっている。静水圧 10 と $15 \mathrm{MPa}$ で は，それぞれ $3.7 〜 6.3 \%$ と $2.3 \sim 6.0 \%$ となっている。P 波速度の 減少率が静水圧の増加に伴って小さくなっている。

Fig.13 は 3 つの測定ケースで得られた積算排水量の経時変化で ある。排水量は分解能 $0.01 \mathrm{~g}$ の電子天秤で測定された。その経時 変化は計 3 つのステージに分けることができる。静水圧 $5 \mathrm{MPa}$ の ケースを例に説明すると，ステージ I ではいずれの測定ケースと もほぼ同じ増加傾向を示している。ステージ II ではともに排水量 が大きく増加しているが, $5 \mathrm{MPa}$ の方が最も増加が著しい。ステー ジIII では排水量が徐々にある平衡状態に達している。

$3 \cdot 3 \mathrm{CO}_{2}$ フロントのモニタリング

含水状態の試料 $\mathrm{TS}$ に $\mathrm{CO}_{2}$ を注入してからの $\mathrm{P}$ 波速度の変化に基
づいて, トモグラフィ解析を行い, $\mathrm{CO}_{2}$ フロントの挙動をモニタリ ングした。静水圧 5 と $15 \mathrm{MPa}$ の両測定ケースを例に, $\mathrm{CO}_{2}$ フロント モニタリングの結果について述べる。Fig.14 と Fig.15では縦軸(Z)が ともに $\mathrm{P}$ 波速度の減少率 $(\%)$ を表している。 $\mathrm{P}$ 波速度が減少した領域 は, $\mathrm{CO}_{2}$ ガスの分布範囲と対応し, その減少率は $\mathrm{CO}_{2}$ ガス飽和度と みな寸ことができる。図中の X 軸は円柱試料の端面の原点 (0) を中心 に展開したものである。また，Y 軸は円柱試料の長軸を表している。

Fig.14 は静水圧 $5 \mathrm{MPa}$ の測定ケースより得られた $\mathrm{CO}_{2}$ フロント の経時変化である。 $\mathrm{CO}_{2}$ ガスは試料下端 (BTM) より注入されてい る。注入開始 20 分後に試料下端では, $\mathrm{P}$ 波速度のわずかな減少が 認められた。注入開始後約 60 分を経過すると, 試料下端のP 波速 度の減少はより鮮明になった。このように $\mathrm{P}$ 波速度の減少を基に $\mathrm{CO}_{2}$ フロントの移動をみると, 試料上端 (TOP) に到達したことを 明瞭に確認できた。P 波速度の減少率が試料下端ほど大きいが, 時 間経過と共に試料上下端の差異は小さくなっている。また, X 軸 方向の $\mathrm{P}$ 波速度の減少率のばらつきが少ない。

Fig. 15 は静水圧 $15 \mathrm{MPa}$ のケースの測定結果である。静水圧 $5 \mathrm{MPa}$ の測定結果と比べて, 同じ経過時間における P 波速度の減少率が 小さく, $\mathrm{X}$ 軸方向における $\mathrm{P}$ 波速度の減少率のばらつきも大きい。 静水圧の増加によって, $\mathrm{CO}_{2}$ 浸透挙動に明瞭な違いが認められた。

\section{4. 考察}

\section{$4 \cdot 1$ 透気係数と孔隙特性}

多孔質砂岩には大小様々な孔隙が存在し, 扁平な孔隙よりも球 形に近いものが多く含まれる ${ }^{14)}$ 。静水圧下における砂岩のひずみ, $\mathrm{P}$ 波速度及び透水 (気) 性は孔隙率のほか, 孔隙の大きさや孔隙構 

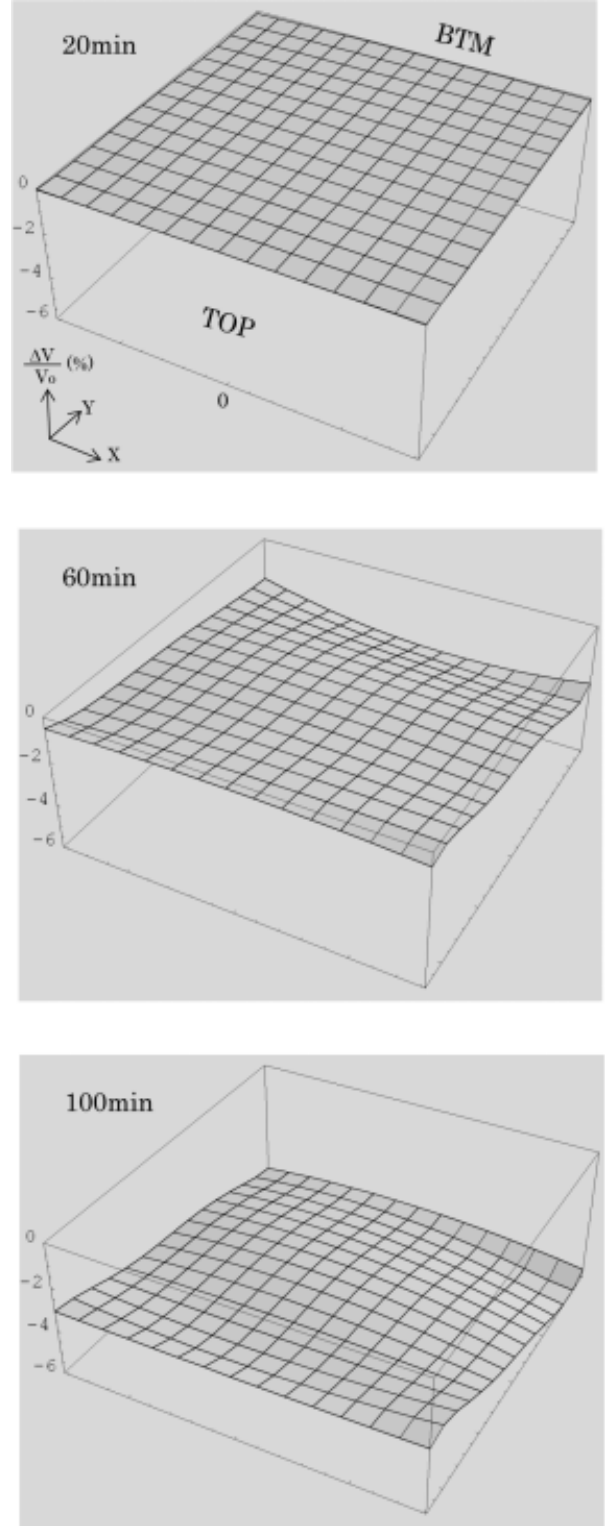

Fig. 14 Reconstructed P-wave velocity changes relative to the P-wave velocity profile when injecting gaseous $\mathrm{CO}_{2}$ into the water-flooded Tako sandstone. The sample was subjected to a constant pressure of 5MPa.

造 (pore structure) にも強く影響される ${ }^{15,16)}$ 。静水圧の負荷によっ て扁平な孔隙が閉鎖されると，砂岩のひずみと $\mathrm{P}$ 波速度は大きく 増加し, 透気性は著しく減少する。

白浜砂岩では静水圧 $10 \mathrm{MPa}$ までにひずみ，P 波速度及び透気係 数の急激な変化がみられた。これは試料に含まれた半径 $0.01 \mu \mathrm{m}$ オーダの孔隙が圧力の負荷によって閉鎖されたと考えられる。ひ ずみと $\mathrm{P}$ 波速度の急激な増加に対応して，透気係数が著しく減少 したことは，閉鎖された孔隙がガスの流路 (flow path) を構成して いたことを示している。静水圧 $10 \mathrm{MPa}$ 以降では透気係数の減少が 小さくなり，10MPa 以上の圧力によって閉鎖される孔隙が少ない ことを示唆している。白浜砂岩に比べて, 多胡砂岩では孔隙の大 きさが約 10 倍大きい。この試料では静水圧の負荷によって閉鎖さ れる孔隙が少ないため, ひずみ, $\mathrm{P}$ 波速度及び透気性に及ぼす影 響は小さかったと解釈できる。

Brace ${ }^{17}$ ) は岩石の孔隙特性 ( 孔隙率, 孔隙の大きさ) と静水圧 〜ひずみ曲線との関係について，つぎのように指摘した。孔隙率 が小さく, 扁平な孔隙が多い岩石では, 静水圧〜ひずみ曲線が上 に凸の形状を示す。孔隙率が大きく, 扁平な孔隙が少ない岩石で
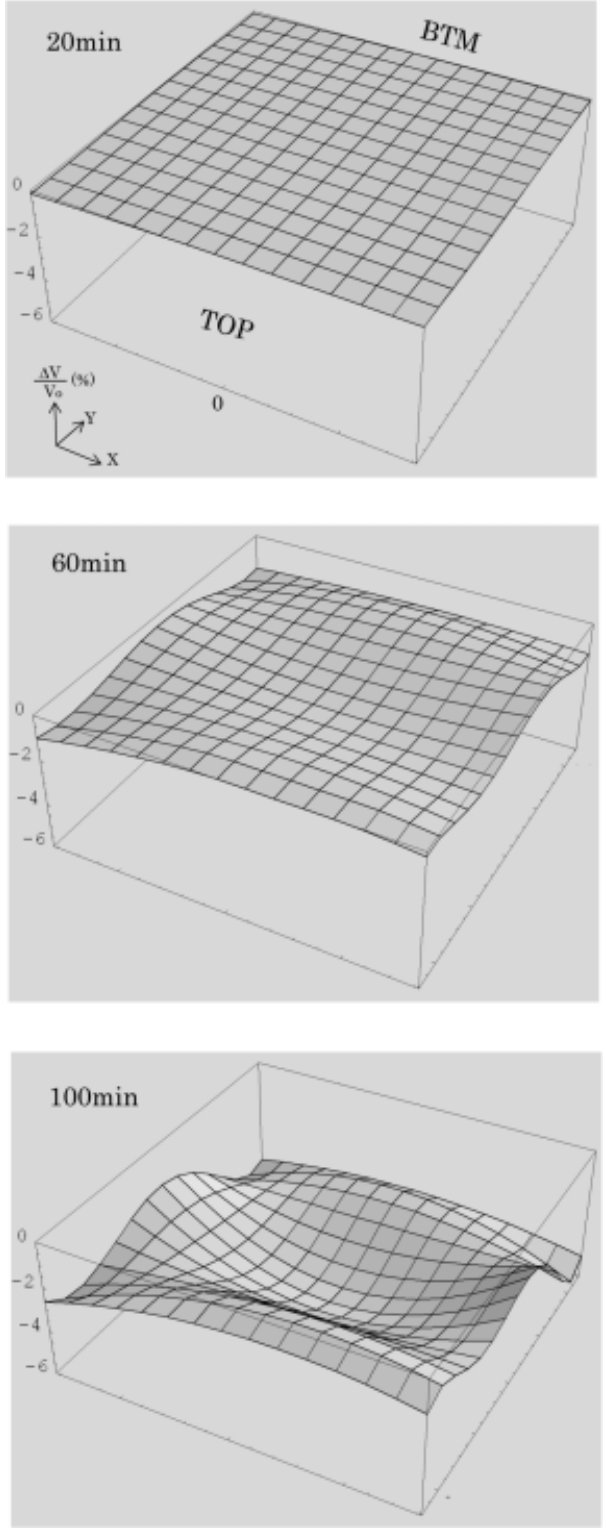

Fig. 15 Reconstructed P-wave velocity changes relative to the P-wave velocity profile when injecting gaseous $\mathrm{CO}_{2}$ into the water-flooded Tako sandstone. The sample was subjected to a constant pressure of $15 \mathrm{MPa}$.

は下に凸の形状をなす。この指摘に基づくと, 本研究に用いた白 浜砂岩は前者, 多胡砂岩は後者にそれぞれ相当する。このように, 静水圧〜ひずみ曲線の形状より, 岩石の孔隙特性を間接的に把握 することが可能である。

\section{$4 \cdot 2 \mathrm{CO}_{2}$ 注入によるP 波速度の変化}

弾性波を利用して石油や天然ガスを探査する手法では, 流体を 含む多孔質砂岩の弾性波速度を評価する場合, 次に示寸 Gassmann の式がよく用いられている。

$$
\begin{aligned}
& V_{p}=\sqrt{\frac{K+(4 / 3) G}{\rho}} \\
& K=K_{d}+\frac{\left(1-K_{d} / K_{s}\right)^{2}}{\phi / K_{f}+(1-\phi) / K_{s}-K_{d} / K_{s}^{2}}
\end{aligned}
$$

ここで， $V_{p}$ はP 波速度， $G$ はせん断係数， $K$ は砂岩が流体を含 む場合の体積弾性率, $K_{d}$ は乾燥状態の砂岩の体積弾性率, $K_{s}$ は砂 岩の固体部分 (solid frame) の体積弾性率, $K_{f}$ は流体の体積弾性率 である。 $\rho$ と $\phi$ はそれぞれ砂岩の密度と孔隙率である。

式 (2) と (3)より, 砂岩の $\mathrm{P}$ 波速度は試料だけでなく, 孔隙中の ガスや水の体積弾性率と密度にも大きく依存寸る。 $\mathrm{CO}_{2}$ ガスの体 
積弾性率は小さく, 式 (3) 右辺の第 2 項がゼロに近いとみなせる ため, 試料の体積弾性率は乾燥状態とほぼ等しい。このため, 透 気実験中に $0.2 \mathrm{MPa}$ で $\mathrm{CO}_{2}$ ガスを注入したが, 両砂岩の $\mathrm{P}$ 波速度 にはほとんど変化がみられなかった。

一方, 乾燥試料に水を注入すると, 試料全体の密度は増加する が，水と試料の体積弾性率があまり変わらないため，式 (2) にお いて体積弾性率 $K$ の増加による効果が相対的に大きい。したがっ て, 測定試料の $\mathrm{P}$ 波速度は注水によって増加した原因は試料の体 積弹性率が相対的に大きくなったためである。注水による試料 SS と TS の P 波速度の増加率を比べると, それぞれ最大で約 $12.5 \%$ と $4.3 \%$ となっている。測定条件がほぼ同じでありながら, 両砂岩 の $\mathrm{P}$ 波速度の増加率に大きな違いが現れたのは重要な意味をもっ ている。同様な現象は $\mathrm{CO}_{2}$ 注入の測定実験でも起こる可能性があ る。注水に伴う $\mathrm{P}$ 波速度の変化について, 孔隙の大きさを考慮し ない Gassmann 式では実測值より数％ほど小さい予測值を得るこ とが報告されている18)。

含水状態の砂岩試料に $\mathrm{CO}_{2}$ ガスを注入すると, 間隙水の一部が 置換されるため, 測定試料は徐々に不飽和へと変わっていく。不飽 和状態にある測定試料の体積弾性率は乾燥状態とあまり変わらな いが, 試料の密度がより大きくなるため, 式 (2)より $\mathrm{P}$ 波速度は小 さくなる。このため, 静水圧が異なる 3 つの測定ケースにおいて, $\mathrm{P}$ 波速度が減少したのは $\mathrm{CO}_{2}$ 注入によって試料 $\mathrm{TS}$ の密度が相対的 に大きくなったためである。今後白浜砂岩への注気実験を再開し, 多胡砂岩の測定結果と比較することにより, 両砂岩の $\mathrm{P}$ 波速度に及 ぼす孔隙の大きさの影響を明らかにする。本研究では間隙水を排出 する試料上端を大気圧下に開放し, $\mathrm{CO}_{2}$ 注入に伴う間隙水圧の増加 による測定結果一の影響を抑えた。弾性波速度のうち, P 波速度は $\mathrm{CO}_{2}$ 飽和度と間隙水圧にともに影響されるが, $\mathrm{S}$ 波速度は間隙水圧 の影響を殆ど受けない ${ }^{19)}$ 。現場で実施される弾性波探查について, $\mathrm{P}$ 波速度と $\mathrm{S}$ 波速度を同時に測定することが望ましいがまだ実施例 が報告されていない。 $\mathrm{S}$ 波速度の測定結果を基に，いかに間隙水圧 の影響を分離するかは今後の研究課題である。

\section{$4 \cdot 3 \mathrm{P}$ 波速度変化に基づく $\mathrm{CO}_{2}$ 挙動のモニタリング}

Fig.14 と Fig. 15 に示した $\mathrm{CO}_{2}$ 注入後の $\mathrm{P}$ 波速度の経時変化は間 接的に $\mathrm{CO}_{2}$ フロントの挙動を表している。簡易トモグラフィ解析 によって得られた $\mathrm{CO}_{2}$ フロントの挙動は $\mathrm{P}$ 波速度と間隙水排出量 の経時変化と調和的である。静水圧 $5 \mathrm{MPa}$ のケースを例に説明す ると, Fig.14において $\mathrm{CO}_{2}$ フロントが試料上端に達したのは注入 開始してから約 30 分後である。これは間隙水排出曲線のステージ $\mathrm{I}$ に相当する (Fig.13 参照)。注入された $\mathrm{CO}_{2}$ は, 間隙水を押し退 けながら試料上端へ移動するが，移動の速さはその圧力条件下の 試料の透水係数に依存する。 $\mathrm{CO}_{2}$ フロントが試料上端に達した後 は, 透気係数が支配的になり, ブレークスルー後の $\mathrm{CO}_{2}$ ガスが排 水ライン内の間隙水を押寸ため, ステージ II では $\mathrm{CO}_{2}$ の流れが急 激に加速されたと考えられる。ステージ II では $\mathrm{CO}_{2}$ ガスとともに 間隙水も一緒に排出されるが, $\mathrm{CO}_{2}$ ガスだけ排出されると, ステー ジIII のとおり間隙水の排出量があまり増えなくなる。

静水圧 $15 \mathrm{MPa}$ の場合, $\mathrm{CO}_{2}$ フロントの形状が $5 \mathrm{MPa}$ のケースと 異なっており, $\mathrm{CO}_{2}$ の流れが複雑になっていることを示唆してい る。また, 間隙水排出量の経時変化は, 静水圧 $5 \mathrm{MPa}$ とよく似てお り，3つのステージに分けることができる。興味深いことに，静水 圧が異なる 3 つの測定ケースとも, ステージII の排水量がほぼ同じ であり，ステージIのみ排水量の違い認められた。ステージ I にお ける排水量は, 試料の透水係数に大きく依存すると考えられる。こ の試料の透水係数は測定していないが, 透気係数をみると, 静水圧 を $5 \mathrm{MPa}$ から $15 \mathrm{MPa}$ まで負荷することにより，透気係数は約 $15 \%$
減少した。この試料では静水圧の負荷に伴ってひずみがほぼ線形的 に増加しており, $\mathrm{P}$ 波速度の増加も少ないことから, 孔隙の閉鎖よ りも変形の方が優勢であるといえよう。つまり, 試料 TS には扁平 な孔隙が少なく, 透気係数の変化は孔隙の変形によるものと考えら れる。孔隙の変形は $\mathrm{CO}_{2}$ が試料上端に達寸るまでの浸透挙動に影 響を与えたため, ステージ I における排水量の違いをもたらしたと 解釈できる。孔隙に含まれる間隙水が注入された $\mathrm{CO}_{2}$ によって, ど のようなメカニズムで置換されるかは今後の研究課題である。

\section{5. 結論}

白浜砂岩と多胡砂岩を用いた透気試験では, 透気係数が孔隙の 大きさに大きく影響されることが明らかになった。白浜砂岩では 扁平な孔隙が静水圧の負荷によって閉鎖されるため, ひずみと $\mathrm{P}$ 波速度は急激に増加し, 透気係数は著しく減少した。多胡砂岩で は扁平な孔隙が少ないため, ひずみ, $\mathrm{P}$ 波速度及び透気係数の急 激な変化はほとんどみられなかった。また, 両砂岩の静水圧〜ひ ずみ曲線の形状には明瞭な違いが認められた。白浜砂岩の場合, 静水圧〜ひずみ曲線が上に凸の形状を呈するが，多胡砂岩ではや や下に凸となっている。これは両砂岩試料に含まれる孔隙特性の 違いを反映していると考えられ，静水圧〜ひずみ曲線の形状より 測定試料の孔隙特性を間接的に把握することが可能である。

乾燥状態の白浜砂岩と多胡砂岩へ水をそれぞれ注入すると, 試 料の $\mathrm{P}$ 波速度はともに増加するが，白浜砂岩の $\mathrm{P}$ 波速度の増加率 がより大きい。注水や注気に伴う $\mathrm{P}$ 波速度の変化は, 砂岩試料の 孔隙特性に大きく影響されるため, 孔隙特性を考慮に入れる必要 がある。含水状態の多胡砂岩に $\mathrm{CO}_{2}$ を注入すると, 孔隙内の間隙 水が $\mathrm{CO}_{2}$ によって置換されるとともに, $\mathrm{P}$ 波速度の減少が認めら れた。静水圧 $5 \mathrm{MPa}$ のケースにおける $\mathrm{P}$ 波速度の減少率が最も大 きく, 圧力が高いケースほど $\mathrm{P}$ 波速度の減少率が小さい。簡易弾 性波卜モグラフィ解析によって得られた $\mathrm{CO}_{2}$ フロントの挙動は置 換された間隙水の排出量の経時変化と調和的である。これは弾性 波を用いた物理探査手法が帯水層に圧入された $\mathrm{CO}_{2}$ の挙動をモ二 タリングする有効性を示している。今後は弾性波速度の変化量を 基に, $\mathrm{CO}_{2}$ と間隙水の置換メカニズムや孔隙内に残留する間隙水 を推定する実験を行う予定である。

\section{References}

1) A. Baklid, R. Korbol and G. Owren : Society of Petroleum Engineering, SPE, 36600 (1996), 269-277.

2) H. Koide, Y. Tazaki, Y, Noguchi, S. Nakayama, M. Iijima, K, Ito and Y. Shindo:Energy Convers. Mgmt, 33(1992), 619-626.

3) S. Tanaka, H. Koide and A. Sasagawa: Energy Convers. Mgmt, 36(1995), 527-530.

4) Van der Meer, L.G.H.: Energy Convers. Mgmt., 34(1993), 959-966.

5) S. Bachu, W.D. Gunter and E. H. Perkins: Energy Convers Mgmt, 35(1994), 269-279.

6) W. Gunter, B. Wiwchar and E. Perkins: Mineralogy and Petrology, 59(1993), 121-140.

7) R. Arts, O. Eiken, A. Chadwick, P. Zweigel, L. van der Meer and B. Zinszner: Proc. 6th Int. Conference of Greenhouse Gas Control Technologies, (2002), pp.347-352.

8) Z. Wang, M. Cates and R. Langan: Geophysics, 63(1998), 1604-1617.

9) Van der Meer, L.G.H.: Energy Convers. Mgmt., 33(1992), 611-618.

10) Z. Wang and A. Nur: Soc. Petr. Eng. Res. Eng., 3(1989), 429-439.

11) Y. Mino, W. Lin, M. Takahashi and K. Nishida: Proc. 33th Geotechnical Engineering Conference, (1989), pp.1243-1244.

12) G. Eischens and A. Swanson: Geotechnical Testing Journal, 19(1996), 232-238.

13) M. Takeda, M. Zhang, T. Ezaki, M., Takahashi and Y., Mitani : J. Japan Society of Eng. Geology, 41(2000), 210-217.

14) L. Caruso, G. Simmons and R. Wilkens : Int. J. Rock Mech. Min. Sci \& Geomech. Abstr., 22(1985), 381-392.

15) R. Wilkens, G. Simmons, T. Wissler and L. Caruso: Int. J. Rock Mech. Min. Sci \& Geomech. Abstr., 23(1986), 313-325.

16) Z. Xue, Y. Ishijima and M. Takahashi: Shigen- to- Sozai, 108(1992), 769-775.

17) W. Brace: Pageoph, 116(1978), 627-633.

18) Z. Xue and T. Ohsumi: Exploration Geophysics, 35(2004), 21-28.

19) M. Toksoz, C. Cheng and A. Timur: Geophysics, 41(1976), 621-645. 